\title{
Water Quality Index of Floodplain River Lubuk Lampam South Sumatera Indonesia
}

\author{
Dade Jubaedah, Sigid Hariyadi, Ismudi Muchsin, and M. Mukhlis Kamal
}

\begin{abstract}
Lubuk Lampam is one of floodplain rivers area and part of this region had been determined as fisheries reserve. It is important to keep the sustainability of the ecosystem as floodplain fish resources. The main problem in this area is water quality degradation that was caused by both, natural and anthropogenic substances. The aims of this study are to determine water quality status and pollution level of the waters, related to the water level fluctuation (flooding periods) and pollutants from oil palm plantations and crude palm oil industry. Water quality status is determined using two methods based on Indonesian goverment regulation, i.e. water pollution index (WPI) and STORET index. The results indicated that Lubuk Lampam floodplain rivers is lightlymoderately polluted based on WPI value, while based on STORET method, the status is moderately-highly polluted.
\end{abstract}

Index Terms-Floodplain rivers, Lubuk Lampam, pollution, pollution index, water quality.

\section{INTRODUCTION}

Lubuk Lampam is one of floodplain arealocated adjacent to River Lempuing as part of the main River Musi system inSouth Sumatera Indonesia. This area is important for local economic growth resulted especially from fisheries and agricultural activities. In order to sustain fisheries resources in the floodplain, the goverment has determined several sites within the floodplain to be fisheries reserves, i.e. Lebung Proyek, Suak Buayo, and Kapak Hulu (Fig. 1).

The floodplain rivers are often disturbed by agricultural development [1]. Diffuse pollution of freshwater, particularly from urban and agricultural land is an on-going problem on floodplain [2]. The main reason for agricultural development of wetland is the fertile or nutrient rich soils in floodplain area, their proximity to a water source and acces to water ways [3]. Land use and land cover change has relationship with water quality. Deforestation due to agricultural activities and increasing demand for settlement imposed threat on water quality degradation [4].

In recent years, extensification of oil palm plantation and industry of crude palm oil is increasing so that reduced the floodplain area. Based on analysis using GIS and remote sensing from Landsat image and Worldview data of 2001

Manscript received May 20, 2014; revised July 17, 2014. This research has been supported by Directorate General of Higher Education, Ministry of Education and Cultural, Indonesia (DIKTI) scholarship (BPPS ) and grant from Sriwijaya University.

The authors are with the Departement of Aquatic Resources Management, Faculty of Fisheries and Marine Sciences, Institut Pertanian Bogor, Bogor 16680, Indonesia and Aquaculture Faculty of Agriculture, Sriwijaya University, Palembang 30662, Indonesia (e-mail: dedejubaedah@fp.unsri.ac.id, sigidh100@yahoo.com,

m_mukhliskamal@yahoo.com). and 2013, it is found that the area of Lubuk Lampam floodplain has decreased about 74.3 ha for oil plam plantation, and this is not include the area used for water channels of oil palm plantation that running across from flooded grasland to the Lempuing river (Fig. 1).

Pollutant and contaminant runoff from oil palm plantations are pesticide (mainly herbicide), organic substances from fertilizer and any other chemicals for agriculture. The palm oil industry produces a wide variety of wastes in large quantities as liquid and solid wastes. Liquid wastes arise from oil extraction and processing, while the solid wastes are the leaves, trunk, decanter cake, empty fruit bunches, seed shells and fibre from the mesocarp. Liquid wastes of crude palm oil commonly referred as palm oil mill effluent [5]. Fresh palm oil mill effluent (POME) characterized by high ammount of total solid $\left(40,500 \mathrm{mgL}^{-}\right.$ ${ }^{1}$ ), oil and grease $\left(4,000 \mathrm{mgL}^{-1}\right)$, Chemical Oxygen Demand, COD $\left(50,000 \mathrm{mLL}^{-1}\right)$ and Biological Oxygen Demand, BOD (25,000 $\left.\mathrm{mgL}^{-1} 1\right)$ [6].

These anthrophogenic substances have potentially negative effects on the water quality of Lubuk Lampam area. On the other hand, the water quality of floodplain has natural behaviour related to its water level fluctuation as indicator of seasonal flooding [7]-[9]. The morphology and water level fluctuation of Lubuk Lampam had been reported [10], [11]. Unfortunatelly, there is a general lack of information about the effect of the anthropogenic substances and decreasing of foodplain area on the water quality of floodplain related to the seasonal flood periods. Hence, the objective of this paper is to determine the water quality status and its relationship to the water level of floodplain area. By studying the relationship between water quality and water level change, issues on sustainability can be addressed and integrated with water protection strategies.

\section{METHODS}

Lubuk Lampam, with an area of 12.000 ha, located in the Ogan Komering Ilir Regency, South Sumatera,Indonesia (Fig. 1).From land to river side, the type of habitats Lubuk Lampam consists of dry land forest (talang), swamp forest (rawang), flooded grassland (lebak kumpai), and river segments. Inside of flooded grassland, there are permanent floodplain pools (lebung). Each type has different inundation periods. During rainy season, all of these area are inundated by water except dry land forest, therefore, the area merge as one unit of aquatic ecosystem. In dry season, all areas become dry, but floodplain pools and main river. Based on the different in inundation periods, sampling sites are determined as follows: 1) upper channel of river Lempuing namely Kapak Hulu (KH), 2) flooded 
grassland(LK1), 3) natural floodplain pools Suak Buayo (SB), 4) man made floodplain pools Lebung Proyek (LP),5)river channel from oil palm plantation (CP), 6) flooded grassland (LK2), and 7) downstream of river Lempuing namely Lempuing Hilir (LH) (Fig. 1).

Sampling campaign was conducted for a year from November 2012 to November 2013.Samples of water were collected monthly except for anthropogenic substances (oil and grease, detergent) that were collected four times (beginning of inundation, inundation periods, highest water level and low water level). Whereas, the anthropogenic substances paraquate and glyphosphate were collected three times (beginning of inundation, highest water level and low water level). The water level data were collected weekly from seven different stations, however, in dry periods, the data only from five stations (the flooded grassland was dry). Temperature, $\mathrm{pH}$, water depth, conductivity, dissolved oxygen (DO) and Secchi disc visibility were observed during the sample collection (insitu). Samples for total nitrite, nitrate, $\mathrm{COD}, \mathrm{BOD}_{5}$, orthophosphate, alkalinity, oil and grease, detergent and herbicide (paraquate and glyphosphate) were stored in polyethylene bottles (except for oil and grease measurement, water samples store in glass bottles and BOD in BOD bottles). Water samples kept nearly at about $4{ }^{\circ} \mathrm{C}$, and delivered immediately to the laboratory and determined according to the APHA standard methods [12].

Nemerow \& Sumitomo's WPI is one of the method to evaluate water quality in an ecosystem [13]-[16], which was originally developed in the United States in the 1970's. Later, it was adopted by the Indonesia Ministry of Environment in the Ministerial Decree No.115/2003 [17], which addresses guidelines to determine the water-quality status. The WPI is a function of $C_{i} / L_{j}$, where $C_{i}$ represents the concentration of parameter $i$ and $L_{j}$ represents the concentration permissible value (PV) of parameter. The WPI for a specific water use $\mathrm{j}\left(\mathrm{WPI}_{j}\right)$ is further expressed by the following equation :

$$
\mathrm{WPI}=\sum_{i}^{n}=1 \sqrt{\frac{\left(C_{i} / L_{i j}\right)_{\max }^{2}+\left(C_{i} / L_{i j}\right)_{a v e}^{2}}{2}}
$$

where, $C_{i}$ is the measured concentration of $i^{\text {th }}$ parameter, $L_{i j}$ is thepermissible value (PV)of the $i^{\text {th }}$ parameter for $j^{\text {th }}$ water usage (i.e.fisheries), and $\left(C_{i} / L_{i j}\right)_{\max }$ and $\left(C_{i} / L_{i j}\right)_{\text {ave }}$ are maximum and average values of $C_{i} / L_{i j}$ for the assigned water usage, respectively. The PV used in this study is based on Indonesian Goverment Regulation No. 82/2001, especially for fisheries water usage [18].The computation result of WPI then classified as one of the 4 catagories as follows:

$$
\begin{gathered}
0.0 \leq \mathrm{WPI} \leq 1.0=\text { not polluted (meets the PV criteria) } \\
1.0<\mathrm{WPI} \leq 5.0=\text { lightly polluted water } \\
5.0<\mathrm{WPI} \leq 10=\text { moderately polluted water } \\
\text { WPI }>10=\text { highly polluted water }
\end{gathered}
$$

STORET method was used in order to evaluate water quality status of water area [19]-[22]. STORET method widely used by goverment and non-goverment agencies based on Indonesia Ministry of Environment's Decree No.115/2003 [17] regarding the guidance in determining water quality status. The basic concept of STORET index is comparingeach of the water quality data to its standard and then scored. The scoring value based on US-EPA (United Sate-Environmental Protection Agency) system. This method needs average, minimum and maximum values of each water quality parameters and therefore need several data (time series data) for each sampling points. The scoringis assigned 0 if the water quality data werein compliance with PV, whereas if the water quality data were above or not in compliance with PV, the score were as presented in Table I.

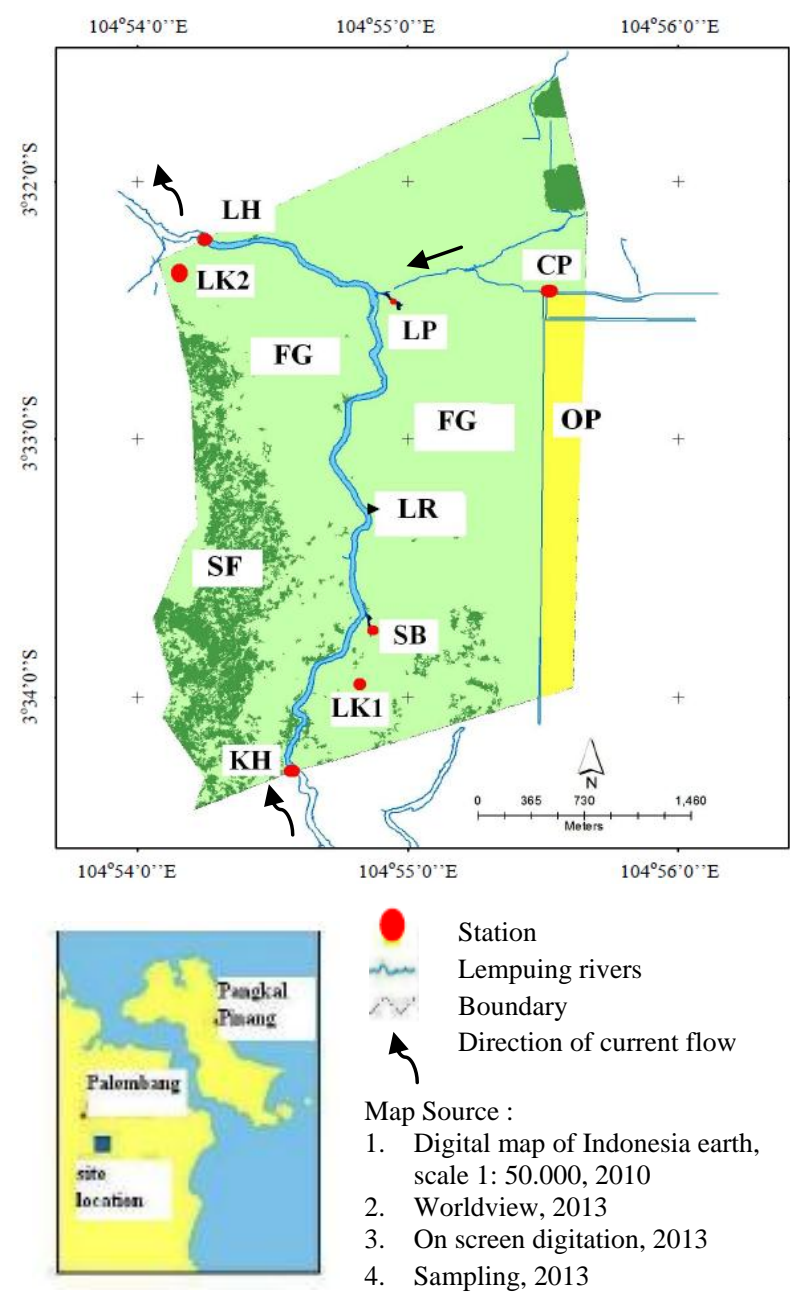

Fig. 1. Study area and sampling stations in LubukLampam Floodplain: Kapak Hulu (KH), flooded grassland 1 (LK1), Suak Buayo (SB), Lebung Proyek (LP), channels of oil palm plantations (CP), flooded grassland 2 (LK2), and Lempuing Hilir (LH), Flooded grassland (FG), swamp forest (SF), Lempuing river (LR), and Oil palm plantation (OP).

TABLE I: SCORING OF EACH WATER QUALITY PARAMETERS VALUE THAT WAS NOT IN COMPLIANCE WITH PERMISSIBLE VALUE (PV) FOR LESS THAN 10 DATA POINTS USED (CANTER [23])

\begin{tabular}{lccc} 
Water quality & \multicolumn{3}{c}{ Score for } \\
\cline { 2 - 4 } parameter value & $\begin{array}{c}\text { Physical } \\
\text { parameter }\end{array}$ & $\begin{array}{c}\text { Chemical } \\
\text { parameter }\end{array}$ & $\begin{array}{c}\text { Biological } \\
\text { parameter }\end{array}$ \\
\hline Maximum & -1 & -2 & -3 \\
Minimum & -1 & -2 & -3 \\
Average & -3 & -6 & -9 \\
\hline
\end{tabular}

The sum of all negatif scores of all parameters is calculated to obtain the STORET Index, then the status of water quality determined according to the following 
classification:

$$
0=\text { not polluted }
$$

-1 to $-10=$ lightly polluted

-11 to $-30=$ moderately polluted

More than $-30=$ highly polluted

\section{RESUlTS AND DISCUSSION}

Water level fluctuation in a year (Fig. 2) showed that during the implementation of research the inundation occurs almost all year around and there was no dry period in flooded grassland. In some occasion the water level in flooded grassland were close to zero point, however there was no indication of dry season. In the normal year, where the different between rainy and dry season is clearly, the flooded grassland area is void of water during dry season.

Based on Fig. 2, it is shown that the inundation cycle of inundation mostly occurs every two months. In flooded grassland,the inundation periods occurs from late December 2012 until the end of May 2013, and the low water level periods occurs from late of May 2013 until November 2013.

This periods was different with fluctuation of average water level fluctuation from 1989 to 2000 on river bank of Lempuing River on the segment at the central of Lubuk Lampam (Fig. 3) [11]. As in [11], inundation periods occurs from late of October until late of June (water level started to increase in October to November, highest water level was observed in December - April, water level was decrease in May-June) and the drought periods from the late of June until begining of October (lowest water level observed in August-September).

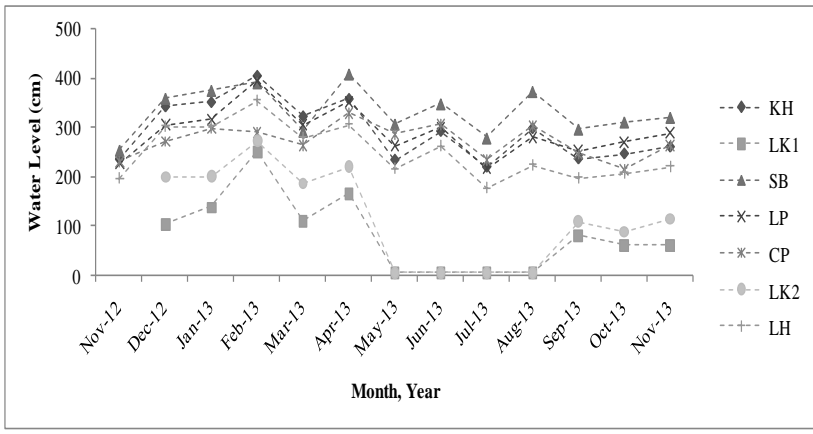

Fig. 2. Water level on sampling location in a year.

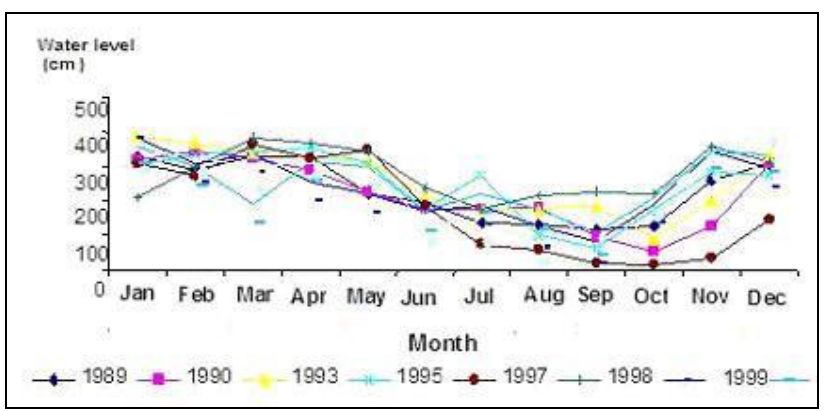

Fig. 3. Water level fluctuation (source : Utomo et al. [20]).

The WPI is applied for evaluating water quality of seven locations, monthly, at different water level (Fig. 4). The results demonstrated that waters in the floodplain area $(\mathrm{KH}$, SB, LP, CP and LH) were highly polluted after highest water level periods in February 2012, while water quality on FG was quite good or meets the PV criteria. Highly polluted water was observed in these area in December 2012 when water level increasedin the beginning of inundation periods. Water quality in most ofthe observation stations were classified as lightly polluted water all year around exceptfor March 2013 at which most of the stationswerein moderatelly polluted water (Table II).

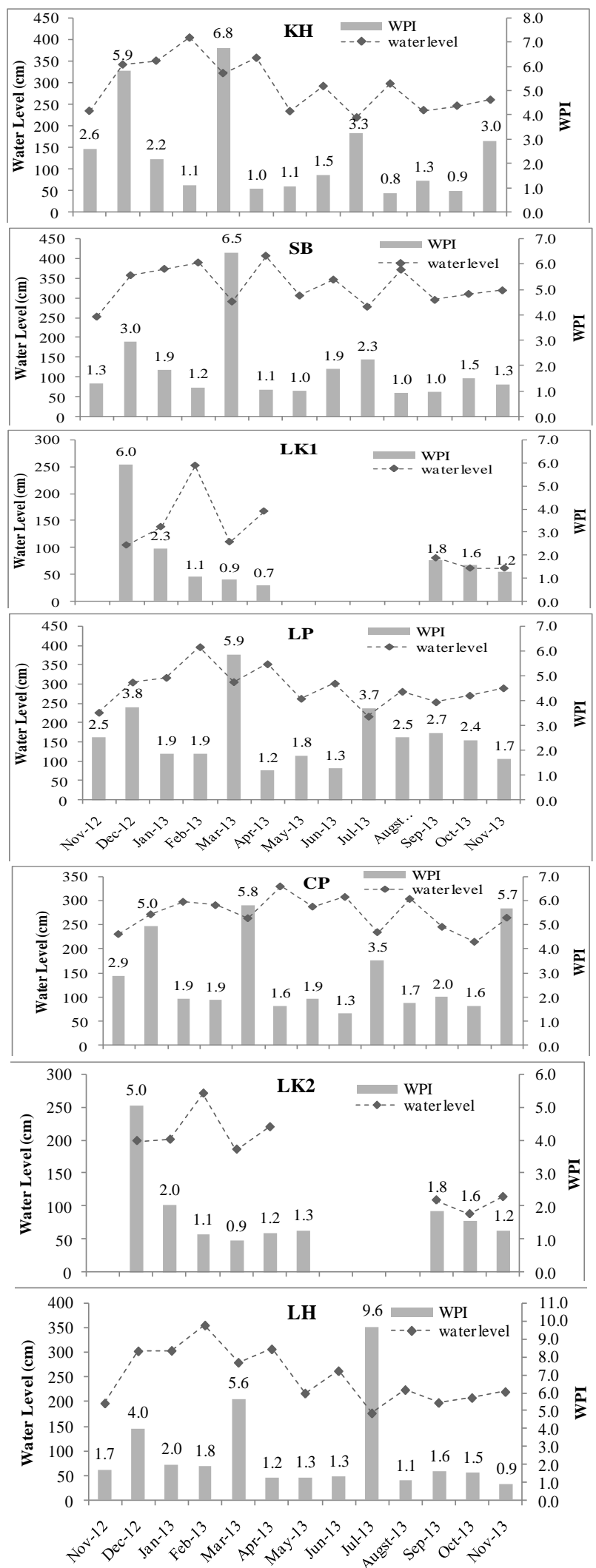

Fig. 4. WPI related to water level at all stations in a year (November 2012 November 2013. 
TABLE II: NumBer AND PERCENTAGE OF STATIONS CLASSIFIED INTO WPI Class

\begin{tabular}{|c|c|c|c|c|c|}
\hline \multirow[b]{2}{*}{$\begin{array}{l}\text { Month, } \\
\text { Year }\end{array}$} & \multirow[b]{2}{*}{ season } & \multirow{2}{*}{$\begin{array}{c}\begin{array}{l}\text { Number } \\
\text { class }\end{array} \\
\text { clean } \\
\text { water } \\
\text { (meets } \\
\text { the PV } \\
\text { criteria) }\end{array}$} & nd percenta & e of stations & for WPI \\
\hline & & & $\begin{array}{r}\text { lightly } \\
\text { polluted } \\
\text { water }\end{array}$ & $\begin{array}{r}\text { moderately } \\
\text { polluted } \\
\text { water }\end{array}$ & $\begin{array}{r}\text { highly } \\
\text { polluted } \\
\text { water }\end{array}$ \\
\hline Nov-12 & Dry & $0(0 \%)$ & $5(100 \%)$ & $0(0 \%)$ & $0(0 \%)$ \\
\hline Dec-12 & Flood & $0(0 \%)$ & $4(57 \%)$ & $3(43 \%)$ & $0(0 \%)$ \\
\hline Jan-13 & Flood & $0(0 \%)$ & $7(100 \%)$ & $0(0 \%)$ & $0(0 \%)$ \\
\hline Feb-13 & Flood & $0(0 \%)$ & $7(100 \%)$ & $0(0 \%)$ & $0(0 \%)$ \\
\hline Mar-13 & Flood & $0(0 \%)$ & $2(29 \%)$ & $5(71 \%)$ & $0(0 \%)$ \\
\hline Apr-13 & Flood & $2(29 \%)$ & $5(71 \%)$ & $0(0 \%)$ & $0(0 \%)$ \\
\hline May-13 & Dry & $0(0 \%)$ & $5(100 \%)$ & $0(0 \%)$ & $0(0 \%)$ \\
\hline Jun-13 & Dry & $0(0 \%)$ & $5(100 \%)$ & $0(0 \%)$ & $0(0 \%)$ \\
\hline Jul-13 & Dry & $0(0 \%)$ & $4(80 \%)$ & $1(20 \%)$ & $0(0 \%)$ \\
\hline Aug-13 & Dry & $2(40 \%)$ & $3(60 \%)$ & $0(0 \%)$ & $0(0 \%)$ \\
\hline Sept-13 & Flood & $1(14 \%)$ & $6(86 \%)$ & $0(0 \%)$ & $0(0 \%)$ \\
\hline Oct-13 & Flood & $1(14 \%)$ & $6(86 \%)$ & $0(0 \%)$ & $0(0 \%)$ \\
\hline Nov-13 & Flood & $1(14 \%)$ & $6(86 \%)$ & $0(0 \%)$ & $0(0 \%)$ \\
\hline
\end{tabular}

Numbers in front of percentage are number stations that include in the categories, total number of stations are seven in flood season whereas in dry season are five station

On March 2013, in the following of highest flood event, water in most stations were classified as moderately polluted except for water in flooded grassland (FG) that observed containing higher concentration of nitrite in that time (Fig. 5). Meanwhile, at FG in the early of inundation on December 2012, it was observed a higher concentration of oil and grease that causing the moderately polluted status (Fig. 6). Nitrite was one of intermediate form of nitrogen in nitrification process. Nitrite is converted from ammonia by bacteria, however, the nitrite is usually converted further to nitrate very rapidly. Nitrite consentration above $0.02 \mathrm{mg} / \mathrm{l}$ usually indicate polluted waters [24]. One of the sources of nitrite is the organic compound from flooded grassland and swamp forest that was inundated whenever highest water level occur. The flood carries suspended or soluble organic and inorganic matter from these area and spreads to all of floodplain area. Flood has an impact on the nutrient status in the floodplain [8]. As the river water level increases, it flooded extensive areas and unloading its nutriet rich sediment [3]. During the flood season, there is connection between the river, channels oil palm plantation and the floodplain, and causing the water in this plain receives a lot of nutrients, due to the quick vegetation remains and humification forest layer decomposition [25]. In addition, the nitrogen from channels of plantation distibuted to all of the area.

The highest concentration of oil and grease on December 2012 may come from the oily wastewater produced during oil extraction process in palm oil mill. Reference [26] stated that wastewaters containing high concentration of oil and grease are increasing in volume due to the expansion in the oil processing industries. The oil and grease subtances may spread out to the area of floodplain. The flooding would increase the water volume, therefore the consentration of oil and grease was decrease at inundation periods.

An annual water quality status in Lubuk Lampam was evaluated based on the WPI and STORET methods (Fig. 7 and 8). WPI showed that water quality status at all stations are classified as lightly and moderately polluted, while based on STORET aremoderately and highly polluted. Based on STORET method, as can be observed from the graph (Fig. 9), the concentration of some water quality parameters were above the permissible values. The parameters were nitrite, orthophosphate, BOD, COD, and oil and grease. In addition, $\mathrm{pH}$ values at almost all observed stations were below the minimum permissible value. This might be considered as natural condition, since one of the floodplain characteristics was acidic water due to humic acid environment [7]-[27].

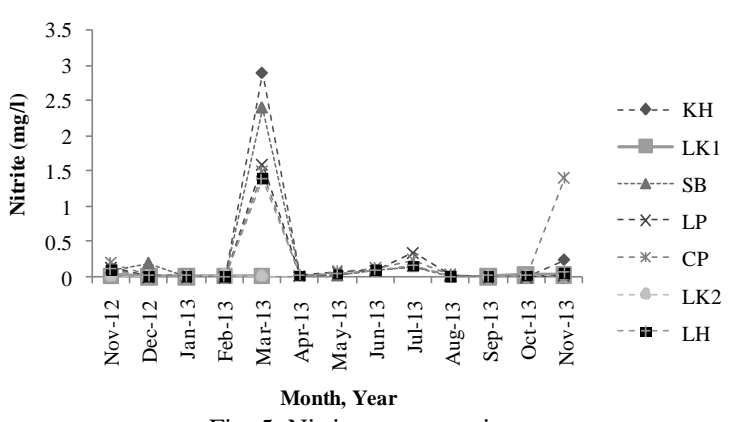

Fig. 5. Nitrite concentration.

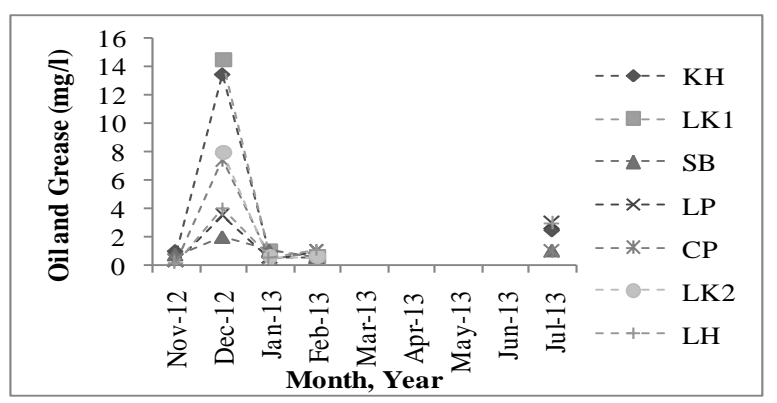

Fig. 6. Oil and grease concentration (no observation from March 2013 to June 2013).

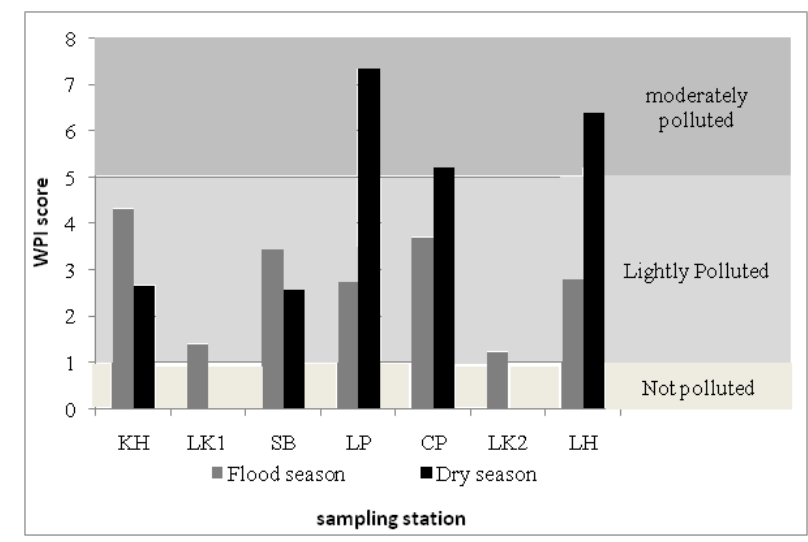

Fig. 7. The status of water quality in Lubuk Lampam floodplain for a year evaluated based on the WPI method.

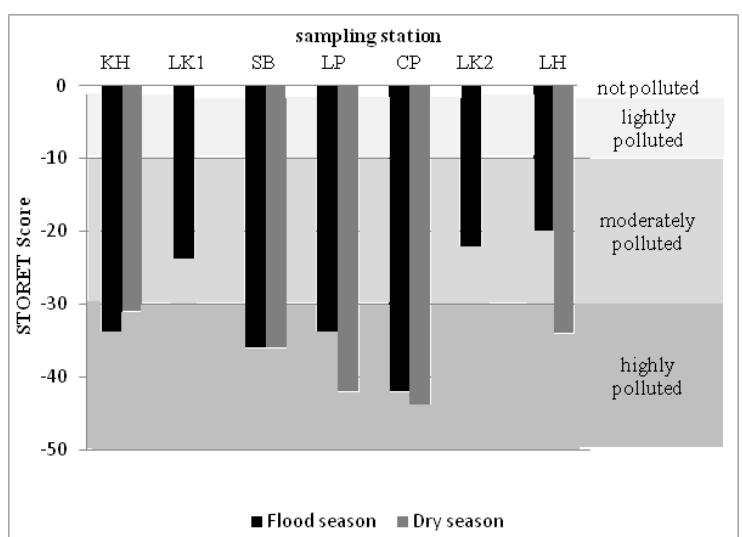

Fig. 8. The status of water quality in Lubuk Lampamfloodplain for a year evaluated based on STORET method. 


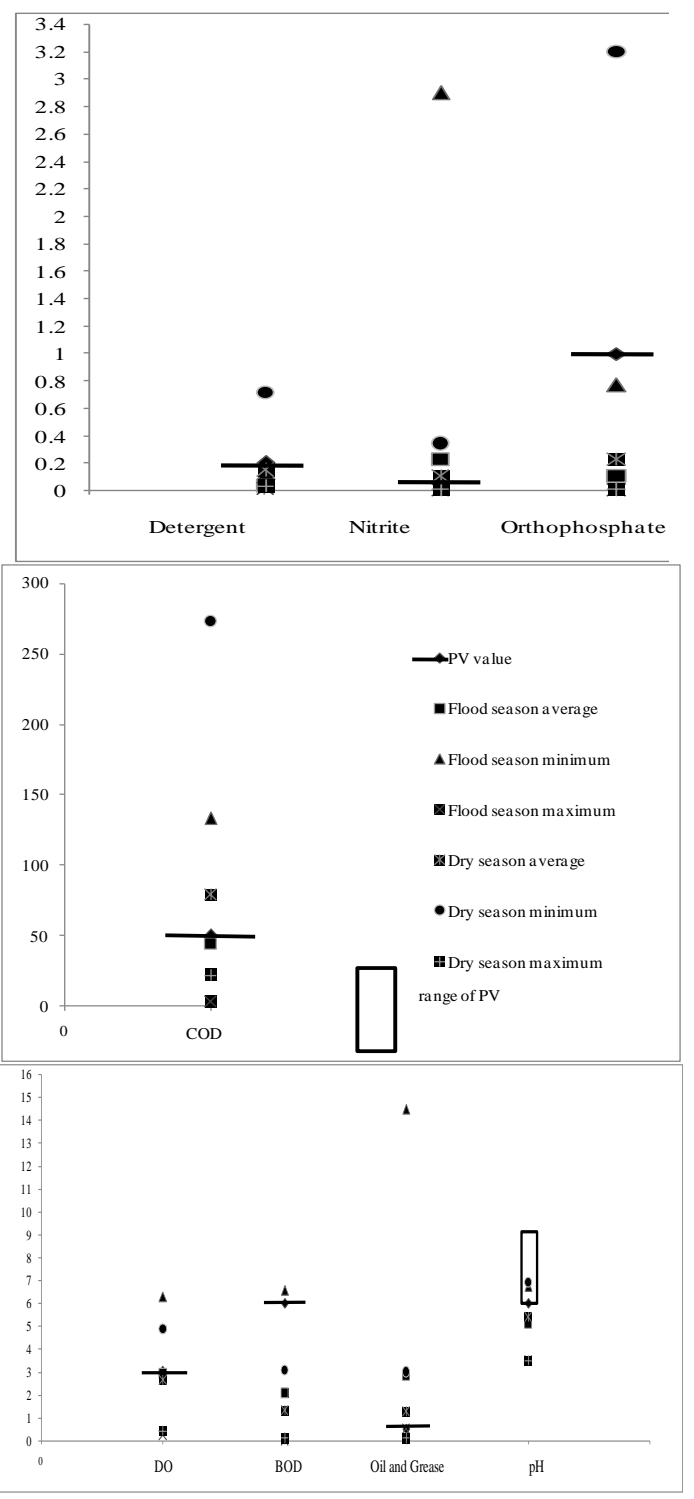

Fig. 9. Seasonal mean of concentrations (average, maximum, minimum) and permissible value of water quality parameters from all of station sampling.
Both WPI and STORET methods (Fig. 7 and 8) demonstrated that station LP, CP, and LH were more polluted in dry periods than in inundation periods except for $\mathrm{KH}$ and SB that shown in contrary condition. The level of pollution in station LP (man made floodplain that has no connection with the river in the dry periods), $\mathrm{CP}$ (Channel of palm-oil plantation) and $\mathrm{LH}$ (downstream at Lubuk Lampam) affected by connectivity among floodplain area. Water quality was better during inundation compared to dry periods when there is connectivity among areas allowing water to mix and exchange, decreasing the concentration of pollution level of water. On the contrary, at the dry periods when there is no connectivity, there is also no water exchange and therefore, the pollutant more concentrated at the area. The stations of $\mathrm{KH}$ and SB (upper river and natural flooded) are the locations at which in inundation periods most likely not only affected by water quality from flooded grassland area but also from the upstream before Lubuk Lampam area, whereas in dry periods when there is no connection between the stations and flooded grassland, the locations are affected only by water quality from the upstream. Water in the flooded grassland (FG) was also classified as polluted, however unlike the other stations, the level of pollution in this area was lower than most of stations (except LH).

The two methods gave the different conclusions of pollution status of the floodplain area. Firdaus and Nakagoshi [5] also support this finding and stated that the different result between the two methods occurs because of different principles of data input in calculation. Each of the two methods have advantages and disadvantages (Table III), however, for the environmental interest the STORET method gave a better precaution than the WPI method. Either ways, it is important to emphazise that the floodplain area including the fisheries reserve was already polluted and need to be managed in maintaining the sustainability of floodplain fish resources.

TABLE III: THE ADVANTAGES AND DISADVANTAGES OF WPI AND STORET METHODS

\begin{tabular}{|c|c|c|}
\hline & \multicolumn{2}{|r|}{ Methods } \\
\hline & WPI & STORET \\
\hline Advantages & $\begin{array}{l}\text { - Can be applied using single data or } \\
\text { observation, therefore, the water quality } \\
\text { status of each point and each observation } \\
\text { can be determined } \\
\text { - Contaminant intensity known directly }\end{array}$ & $\begin{array}{l}\text { - The calculation method is simpler and faster } \\
\text { - Easy to identify which contaminant causing } \\
\text { pollution } \\
\text { - More sensitive and representative }\end{array}$ \\
\hline Dis-advantages & $\begin{array}{l}\text { - Less sensitive } \\
\text { - The calculation more complex, involves } \\
\text { many steps }\end{array}$ & $\begin{array}{l}\text { - Need more than one data set (time series data or } \\
\text { several data from several points in the area) } \\
\text { - Can not be applied for single data set }\end{array}$ \\
\hline
\end{tabular}

\section{CONCLUSIONS}

The water quality status of Lubuk Lampam floodplain area is polluted, especially in the beginning of inundation periods and after the highest water level. Based on the results of two methods, there were different status of pollution level of the floodplain, namely lightly-moderately polluted (WPI) and moderately-highly polluted (STORET). Nitrite and anthropogenic substances oil and grease were the major parameters causing the pollution based on WPI, while $\mathrm{pH}$, nitrite, orthophosphate, BOD, COD, and anthropogenic substances (detergent,oil and grease) were not in compliance with permissible value and causing pollution based on STORET method.

\section{ACKNOWLEDGMENT}

We are grateful to: Departement of Aquatic Resources Management Faculty of Fisheries and Marine Sciences IPB, Fisheries Laboratory of Sriwijaya University, Environment Laboratory of South Sumatera Environment Agency, Agrochemicals Residues Laboratory of Environmental Research Institute of Agriculture, andResearch Institute for 
Inland Water Fisheries.

\section{REFERENCES}

[1] F. D. Shields Jr, R. E. Lizotte Jr, and S. S. Knight. (18 August, 2011). Floodplain river backwater restoration: A case study. River Res. and Applic. [Online]. p. 17. Available: http://www.wileyonlinelibrary.com

[2] C. Peacock, Rivers, Floodplains and Wetlands: Connectivity and Dynamics, RSPB, 2003, pp. 1-64.

[3] J. T. A. Verhoven and T. L. Setter. (August 2009). Agricultural use of wetlands: Opportunities and limitations. Ann Bot. [Online]. 105(1). pp 155-163. Available: http://www.ncbi.nlm.nih.gov

[4] R. Firdaus and N. Nakagoshi. (November 2013). Assesment of the relationship between land use land cover and water quality status of the tropical watersheed: A case of Batang Merau watershed, Indonesia. J. Bio.\&Env. Sci. [Online]. 3(11). pp. 21-30. Available: http://www.innspub.net

[5] R. P. Singh, M. H. Ibrahim, N. Esa, and M. S. Iliyana, "Composting of waste from palm oil mill: A sustainable waste management practice," Rev Environ Sci Biotechmol.,vol. 9, pp. 331-344, February 2010.

[6] A. N. Ma, "Environmental management for the oil palm industry," Palm Oil Dev., vol. 30, pp. 1-10, 2000.

[7] R. L. Welcomme, Fisheries Ecology of Floodplain Rivers, Longman Inc., New York, 1979, pp. 40-53.

[8] W. J. Junk, "Ecology of Floodplain - A Challenge for Tropical Limnology," in Perspectives in Tropical Limnology, F. Schiemer and K. T. Bolands, Eds. RSPB Academic Publishing by Amsterdam, The Netherlands, 2006, pp. 255-265.

[9] W. J. Junk and P. B. Bayle, "The scope of the flood pulse concepts regarding riverine fish and fisheries, given geographic and man-made differences between systems," in Proc. American Fisheries Society Symposium, 2007, pp. 587-603.

[10] Samuel, "The morphology of lubuk lampam floodplain," in Fisheries Ecology and Management of Lubuk Lampam Floodplain River, South Sumatera, D. I. Hartoto, S. Koeshendrajana, E. S. Kartamihardja, A. D. Utomo, Z. Nasution, Eds. Research Institute for Inland Water Fisheries, Research Center for Capture Fisheries, Agency of Marine and Fisheries Research, Ministry of Marine and Fisheries Affairs, Palembang, 2008, pp. 1-7.

[11] A. D. Utomo, S. Kaban, and D. I. Hartoto, "Correlation of water level fluctuation to physico-chemical features of Lubuk Lampam floodplain," in Fisheries Ecology and Management of Lubuk Lampam Floodplain River, South Sumatera, D. I. Hartoto, S. Koeshendrajana, E. S. Kartamihardja, A. D. Utomo, Z. Nasution, Eds. Research Institute for Inland Water Fisheries, Research Center for Capture Fisheries, Agency of Marine and Fisheries Research, Ministry of Marine and Fisheries Affairs, Palembang, 2008, pp. 8-15.

[12] APHA (American Public Health Associaton), Standar Methods for the Examinationof Water and Wastewater, 18th edition, American Public Health Association, American Water Works Association and Water pollution Control Federation (APHA, AWWA and WPCF). Washington D.C., 1998.

[13] N. L. Nemerow and H. Sumitomo, "Benefit of water quality enhancement," Water Pollution Control Reserach Series Report DAJ $1611012 / 70[Z]$, U.S Environmental Protection Agency, Water Quality Office, Syracuse University, Syracuse, New York, December 1970.

[14] J. Chen, Q. Liu, and H. Qian, "Application of improved Nemerow index method based on entropy weight for groundwater quality evaluation," International Journal of Environmental Sciences, vol. 3 pp. 1284-1290, February 2012.

[15] K. Nachiyunde, H. Ikeda, K. Tanaka, and Kozaki. (January 2013). Evaluation of portable water in five provinces of Zambia using a water pollution index. African Journal of Environmental Sciences and Technology. [Online]. 7(1). pp. 14-29. Available: http://www.academicjournals.org/AJEST

[16] E. Suwandana, "Comparative study on water quality assesment between urban and rural watersheed: A case study of Ciliwung and Ciujung watersheed, Indonesia," Ph.D. dissertation, International Development and Cooperation Hiroshima University, Japan, 2012.

[17] Ministry of Environment of Indonesia, The Guidance of Water Quality Status in Indonesia Decree, no. 115, 2003.

[18] Indonesian Goverment Regulation, Regarding the Water Quality Management and Water Pollution Control, no. 82, 2001.

[19] B. C. Matahelumual, "STORET method to determine water quality status in Bantar Gebang (Penentuan status mutu air dengan sistem STORET di Kecamatan Bantar Gebang)," Journal Geologi Indonesia, vol. 2, pp. 113-118, June 2007.
[20] A. J. S. Debby, E. M. Adiwilaga, R. Dahuri, I. Muchsin, and H. Effendi, "Spatial distribution of polluted area and analysis organic pollution impact in Teluk Ambon Dalam (Sebaran spasial luasan area tercemar dan analisis beban pencemaran bahan organik pada perairan Teluk Ambon Dalam)," Torani, vol. 19, pp. 96-106, August 2009.

[21] M. N. Suparjo, "Water pollution in Babon river, Semarang (Kondisi pencemaran perairan sungai Babon Semarang),"Journal Saintek Perikanan, vol. 4, pp. 38-45, 2009.

[22] T. Setiadi and J. Fahana, "Development application to determine polluted area home industry pollution based on system information geografis (Pengembangan aplikasi untuk menentukan daerah pencemaran limbah home industry berbasis sistem informasi geografis)," Journal Informatika, vol. 4, pp. 488-495, July 2010.

[23] L. W. Canter, Environmental Impact Assesment, University of Oklahoma, McGraw-Hill Book Company, New York, 1977, pp. 86118.

[24] N. Mesner and J. Geiger. (December 2010). Nitrogen. Utah State University water Quality Extention. [Online]. pp. 1-4. Available: http://extenxion.usu.edu/waterquality/

[25] R. C. Galavoti, A. A. V. A. Ohnuma Jr., J. P. M. de Andrade, N. P. de Almeida, F. Bottino, and E. M. Mendiondo, "Sustainable handling of the river basin/river/floodplain system for the conservation of wate resources in urban areas," Novatech, 2010, pp. 1-10.

[26] A. O. Alade, A. T. Jameel, S. A. Muyubi, M. I. A. Karim, and M. Z. Alam, "Removal of oil and grease as emerging pollutants of concer (EPC) in wastewater stream," IIUM Engineering Journal, vol. 12, pp. 161-169, 2011.

[27] T. Vegas-Vilarrủbia and R. Herrera, "Seasonal alternation of lentic/lotic conditions in the Mapire system, a tropical floodplain lake in Venezuela," Hydrobiologia, vol. 262, pp. 43-55, 1993.

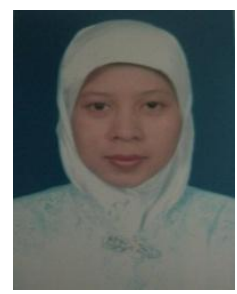

Dade A. Jubaedah was born in Majalengka West Java, Indonesia on July 21, 1977. She did her bachelor degree in aquaculture from the Faculty of Fisheries and Marine Sciences, Diponegoro University, Semarang, Central of Java, Indonesia and master degree of sciences in aquatic sciences from the Faculty of Fisheries and Marine Sciences, Bogor AgriculturalUniversity, Bogor, West Java, Indonesia.

She is also a PhD candidate at the Study Program of Aquatic Resources Management, Bogor Agricultural University, where she furthers research on water quality on floodplain rivers in South Sumatera Indonesia.

She is a lecturer at the Study Program Aquaculture, Faculty of Agriculture, Sriwijaya University, Palembang, South Sumatera, Indonesia. She has presented papers at national and international conferences, published articles and papers in various journals. She was the head and a member of some environmental impact analysis studies and monitoring of enviromental management, i.e. Sinar Mas group agro-forestry, Indonesia. She has no book published yet. Her main area of interest is the water quality and environmental sciences related to management and fisheries culture.

She joined ISOI South Sumatera, Ikatan Sarjana Oseanografi Indonesia, Association of oceanology Bachelor Degree, Indonesia in 2001 and The Society of Indonesian Environmental Journalists (SIEJ) in 2014.

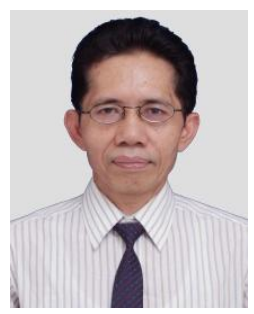

Sigid Hariyadi was born in Malang, East Java on November 18, 1959. He received his $\mathrm{PhD}$ degree in aquatic sciences from Bogor Agricultural University in 2011 and participated sandwich program in Auburn Unversity in 2008. He received the M.Sc degree in 1991 in water quality management from the Fisheries and Allied Aquacultures Departement, Auburn Unversity, Alabama, USA. He did his BA degree in aquatic resources management from Bogor Agricultural

\section{University in1983.}

$\mathrm{He}$ is a lecturer at Aquatic Resouces Management Bogor Agricultural University. He currently is the head of post graduate program (master degree and doctoral program) at the Departement of Aquatic Resources Management, Faculty of Fisheries and Marine Sciences, Bogor Agricultural University, Indonesia. He is a member of the Environmental Research Center (PPLH), Bogor Agriculture University. He has extensive experience in research and became the trainer concerned with the environmental impact analysis and aquatic resources management. He was the head and a member of some environmental impact analysis studies and monitoring of enviromental management for more than 50 industries. $\mathrm{He}$ has published numerous articles in refered journals and conference 
proceedings both national and international. His main areas of interest are in water quality and aquatic environmental pollution (mainly the impact, monitoring, evaluation and management).

Dr. Hariyadi was a member of American Society of Limnology and Oceanography (ASLO) from 1990 to 1994, National Geographic Society from 1990 to 1993, Association of Indonesian Fisheries Bachelor Degree (Ikatan Sarjana Perikanan Indonesia, ISPIKANI) from 2008 to 2011 and Indonesian Society of Limnology (Masyarakat Limnologi Indonesia, MLI) since August 2012.

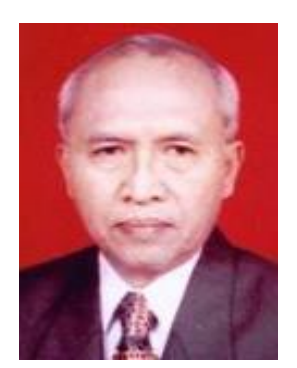

Ismudi Muchsin was born in Temanggung, Central of Java, Indonesia on November 20,1941 $\mathrm{He}$ holds the BSc degree in freshwater fisheries, Bogor Agricultural Sciences, Bogor Indonesia in 1976 and Dr. Degree in ichtyologie appliquee from INP-de Toulouse, French in 1984.

$\mathrm{He}$ is a lecturer and professor in population dynamics of fish. He was the dean of the Faculty of Fisheries, Bogor Agricultural Unversity, Bogor, Indonesia and emeritus professor. His previous research interests are ecology and biology of eel (Anguilla spp) in river and lake Poso, central Sulawesi, management of fisheries resources and biological aspects of Glossogobius giuris HB on lake Tempe South Sulawesi, growth rate and mortality rate of Oreochromis mossambicus (Peter) in Seloredo dam, Malang, East Java. He has published numerous articles. He has published a book "Pengelolaan sumber daya pesisir dan laut". His research interest includes areas of fish population dynamics, eco-biology and management.

Prof. Muchsin is a member of Toulousein Ichtyologie Appliquie Association and Indonesian Fisheries Association. He received an award as a second best lecturer of Bogor Agricultral University in 1986 and research award from ministry of research of Republic of Indonesia (US\$45,000) from 2001 to 2003. He was a reviewer of research proposal from lecturer of Indonesia universities which been proposed to Directorate General of Higher Education from 1998 to 2008, the head of rector election committee from 2002 to 2003 and the secretary of Senate Bogor Agricultural University from 2001 to 2003 . He is also a member of Board of Trustee of IPB from 2000 to 2003.

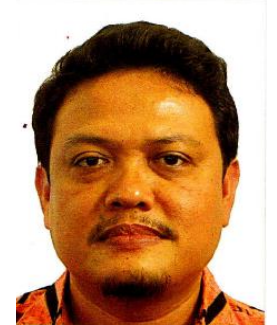

M. Mukhlis Kamal was born in Subang, West Java on September 14, 1968. He did his BA degree in aquatic resources management majoring in fish bioecology in Bogor Agricultural University from 1987 to 1992 , master degree of sciences in Institut of Biological Sciences, Aarhus University, Denmark, majoring in fish respiration physiology from 1997 to 1999 and $\mathrm{PhD}$ degree from Institute for Marine Research, University of Kiel, Germany majoring in fish larval growth from 2000 to 2004

He has been a lecturer at the Bogor Agricultural University since 1994 until now. He has became the head of the Study Program of the Department of Living Aquatic and Resources Management, coordinator of students affairs at the Faculty of Fisheries and Marine Science, Bogor Agricultural University and secretary of departement. Since 2014, he has became the head of the Aquatic Resources Management Departement, Faculty of Fisheries and Marine Sciences, Bogor Agriculural University. He was a vice manager of the sandwich program between IPB and ZMT Bremen, Germany, Ryukyus University, Okinawa, Japan, and Aarhus University, Denmark. He also became an environmental consultant at PT. Saran Widya Sempurna for fish biology division. His research and publication interest include fish biodiversity in freshwater and marine environment, fish larvae, fish reproductive biology and dynamics.

Dr. Kamal is a reviewer for journal of Bawal (Ministry of Marine and Fisheries, Indonesia). $\mathrm{He}$ is a member of Indonesia Ichthyology Community (Masyarakat Ikhtiologi Indonesia, MII) and Association of Indonesia Environmental Observers. 